www.nature.com/jhg

\title{
Molecular basis of hereditary cardiomyopathy: abnormalities in calcium sensitivity, stretch response, stress response and beyond
}

\begin{abstract}
Akinori Kimura
Cardiomyopathy is caused by functional abnormality of cardiac muscle. The functional abnormality involved in its etiology includes both extrinsic and intrinsic factors, and cardiomyopathy caused by the intrinsic factors is called as idiopathic or primary cardiomyopathy. There are several clinical types of primary cardiomyopathy including hypertrophic cardiomyopathy (HCM) and dilated cardiomyopathy (DCM). Linkage studies and candidate gene approaches have explored the disease genes for hereditary primary cardiomyopathy. The most notable finding was that mutations in the same disease gene can be found in different clinical types of cardiomyopathy. Functional analyses of disease-related mutations have revealed that characteristic functional alterations are associated with the clinical types, such that increased and decreased $\mathrm{Ca}^{2+}$ sensitivity due to sarcomere mutations are associated with HCM and DCM, respectively. In addition, our recent studies have suggested that mutations in the Z-disc components found in HCM and DCM may result in increased and decreased stiffness of sarcomere; that is, stiff sarcomere and loose sarcomere, respectively, and hence altered stretch response. More recently, mutations in the components of I region were found in hereditary cardiomyopathy and the functional analyses of the mutations suggested that the altered stress response was associated with cardiomyopathy, further complicating the etiology and pathogenesis. However, elucidation of genetic etiology and functional alterations caused by the mutations shed lights on the new therapeutic approaches to hereditary cardiomyopathy, such that treatment of $\mathrm{DCM}$ with a $\mathrm{Ca}^{2+}$ sensitizer prevented the disease in a mouse model.
\end{abstract}

Journal of Human Genetics (2010) 55, 81-90; doi:10.1038/jhg.2009.138; published online 15 January 2010

Keywords: calcium sensitivity; cardiomyopathy; mutation; stress response; stretch response

\section{INTRODUCTION}

Cardiomyopathy is a heterogeneous disease caused by functional abnormality of cardiac muscle and classified into primary cardiomyopathy and secondary cardiomyopathy. ${ }^{1}$ Secondary cardiomyopathy is defined as cardiomyopathy caused by extrinsic factors including ischemia, hypertension and metabolic disorders. On the other hand, diagnosis of primary cardiomyopathy is based on the exclusion of secondary cardiomyopathy and there are several different clinical types. ${ }^{2,3}$ Hypertrophic cardiomyopathy (HCM) and dilated cardiomyopathy (DCM) are two major clinical types of primary cardiomyopathy that had been defined as 'idiopathic'; that is, of unknown etiology. HCM, a major cause of sudden death in young and heart failure, is characterized by left ventricular hypertrophy, often asymmetric, accompanied by myofibrillar disarrays and reduced compliance (diastolic dysfunction) of cardiac ventricles. In contrast, DCM is characterized by dilated ventricular cavity with systolic dysfunction. Clinical symptom of DCM is heart failure and often associated with sudden death. There are other clinical types of cardiomyopathy.
Restrictive cardiomyopathy (RCM) is accompanied by increased stiffness of the myocardium with diastolic dysfunction without significant hypertrophy. ${ }^{4}$ In addition, arrhythmogenic right ventricular cardiomyopathy (ARVC) is characterized by a dilated dysfunctional right ventricle (RV), ventricular arrhythmias and fibrofatty replacement of the RV. Another cardiomyopathy is left ventricular noncompaction (LVNC) characterized by less trabeculations in the left ventricle (LV), as well as LV hypertrophy and/or dilation. ${ }^{1}$

The etiology of primary cardiomyopathy had been unknown, but various genetic abnormalities associated with the cardiomyopathy have been unraveled in the past two decades. More than half of HCM patients have family history of the disease consistent with autosomal dominant genetic trait. ${ }^{5}$ In the case of DCM, about $20-35 \%$ patients had family history of the disease, mainly consistent with the autosomal dominant inheritance, although some familial cases can be explained by autosomal recessive or X-linked recessive trait. ${ }^{6,7}$ Familial occurrence is also noted in RCM, ARVC and LVNC. ${ }^{1-4}$ As the presence of family history suggested the genetic etiology of the

Department of Molecular Pathogenesis, Medical Research Institute, and Laboratory of Genome Diversity, Graduate School of Biomedical Science, Tokyo Medical and Dental University, Tokyo, Japan

Correspondence: Professor A Kimura, Department of Molecular Pathogenesis, Medical Research Institute, Tokyo Medical and Dental University, 1-5-45 Yushima, Bunkyo-ku, Tokyo 113-8510, Japan.

E-mail: akitis@mri.tmd.ac.jp

Received 22 November 2009; revised 8 December 2009; accepted 9 December 2009; published online 15 January 2010 
disease, linkage studies in multiplex families were taken to identify the disease loci in each family. Identification of the disease loci has enabled one to decipher the disease-linked mutations in the genes located within the loci. Subsequently, other candidate gene analyses, focused on the genes encoding for proteins related or interacting with products of the disease genes, have been successful in unraveling novel disease genes. As shown in Table 1 many different disease genes were identified. The most important point is the overlapping of disease genes for different clinical types.

\section{SARCOMERE MUTATIONS IN HCM}

Identification of a missense mutation in cardiac $\beta$-myosin heavy chain gene (MYH7) linked to HCM in a large multiplex family was the first demonstration of the disease gene for $\mathrm{HCM}^{8}$ Subsequently, many investigators have analyzed MYH7 for mutations in HCM patients and many different missense mutations were identified as the cause. However, frequency of MYH7 mutations in the patients was less than half and there were many families not linked to the MYH7 locus. Linkage studies in such non-MYH7-linked HCM families have revealed mutations in $\alpha$-tropomyosin gene (TPM1), cardiac troponin $\mathrm{T}$ gene (TNNT2) and cardiac myosin binding protein- $\mathrm{C}$ gene (MYBP3) as the causes of HCM. As these genes encode for components of sarcomere involved in muscle contraction, genes for other sarcomere components were analyzed and lead to the identification of $\mathrm{HCM}$-associated mutations in ventricular myosin essential light chain gene (MYL3), ventricular myosin regulatory light chain gene (MYL2), cardiac troponin I gene (TNNI3), cardiac $\alpha$-actin (CACT) and cardiac troponin C (TNNC1). Therefore, mutations in any components of sarcomere can result in HCM. . $^{3,5}$

Our study has showed that sarcomere mutations are found in about $40 \%$ of East Asian (Japanese and Korean) patients with familial HCM in the heterozygous state, consistent with the autosomal dominant inheritance (Table 2). About 20, 10 and $10 \%$ of patients carried mutations in MYH7, TNNT2 and MYBPC3, respectively, whereas a few cases had mutations in other components of sarcomere such as MYL2, MYL3 and TNNI3. So far investigated, we found no patient who had mutations in two or more disease genes, although there were some patients who were homozygous for the sarcomere mutation. The homozygous patients showed severer clinical manifestations than the heterozygous patients in the family, demonstrating the gene dose of mutation. ${ }^{9}$ Disease-related mutations can also be found in sporadic HCM (Table 2). We found one de novo case, ${ }^{10}$ but the other sporadic cases were probably due to the low penetrance of the mutation, because most of the mutations found in the sporadic HCM patients can also be found in other patients with familial HCM.

The most striking impact of unraveling disease genes and diseasecausing mutations is not only that the etiology and pathogenesis of cardiomyopathy are understood but also that the genetic testing will be at least in part available for the cardiomyopathy. The genetic testing is useful for the provision of prognosis and more specifically predicting risk for unfavorable outcome such as sudden cardiac death or heart failure. From the beginning of unraveling disease-causing mutations, genotype-phenotype correlation analyses was one of the main focus and such analyses were mainly reported for HCM. Clinical manifestations of HCM due to the sarcomere mutations were in general different from each other, but there were some tendencies of genotype-phenotype correlations. ${ }^{11,12}$ For example, Watkins et al. ${ }^{13}$ hypothesized that the MYH7 mutations leading to amino acid changes with charge alteration was associated with poor survival prognosis. However, it is not simply applicable to all the MYH7 mutations. As shown in Figure 1, three different MYH7 mutations, Arg249Gln,
Table 1 Disease genes for hereditary cardiomyopathy

Gene

Clinica phenotype Heredity symbol Coding protein

\begin{tabular}{|c|c|c|c|}
\hline $\mathrm{HCM} / \mathrm{DCM} / \mathrm{RCM} / \mathrm{LVNC}$ & $A D$ & MYH7 & Cardiac $\beta$-myosin heavy chain \\
\hline $\mathrm{HCM} / \mathrm{DCM} / \mathrm{RCM} / \mathrm{LVNC}$ & $A D$ & TNNT2 & Cardiac troponin $\mathrm{T}$ \\
\hline $\mathrm{HCM} / \mathrm{DCM}$ & $A D$ & TPM 1 & $\alpha$-tropomyosin \\
\hline HCM/DCM & $A D$ & MYBPC3 & Cardiac myosin binding protein-C \\
\hline $\mathrm{HCM}$ & $A D$ & MYL3 & Ventricular myosin essential light chain \\
\hline $\mathrm{HCM}$ & $A D$ & MYL2 & Ventricular myosin regulatory light chain \\
\hline $\mathrm{HCM} / \mathrm{DCM} / \mathrm{RCM}$ & $A D$ & TNNI3 & Cardiac troponin I \\
\hline $\mathrm{HCM} / \mathrm{DCM} / \mathrm{LVNC}$ & $A D$ & ACTC & Cardiac $\alpha$-actin \\
\hline $\mathrm{HCM} / \mathrm{DCM}$ & $A D$ & TTN & Titin, connectin \\
\hline $\mathrm{HCM} / \mathrm{DCM}$ & $A D$ & TNNC1 & Cardiac troponin $\mathrm{C}$ \\
\hline $\mathrm{HCM}$ & $A D$ & MYH6 & Cardiac $\alpha$-myosin heavy chain \\
\hline $\mathrm{HCM} / \mathrm{DCM}$ & $A D$ & CSRP3 & Muscle LIM protein, MLP \\
\hline $\mathrm{HCM}$ & $A D$ & CAV3 & Caveolin-3 \\
\hline $\mathrm{HCM} / \mathrm{DCM}$ & $A D$ & TCAP & Titin-cap, Tcap, telethonin \\
\hline $\mathrm{HCM} / \mathrm{DCM}$ & $A D$ & $V C L$ & Metavinculin \\
\hline $\mathrm{HCM}$ & $A D$ & $J P H-2$ & Junctophilin-2 \\
\hline $\mathrm{HCM}$ & $A D$ & OBSCN & Obscurin \\
\hline $\mathrm{HCM}$ & $A D$ & MYOZ2 & Myozenin, calsartin-1 \\
\hline $\mathrm{HCM} / \mathrm{DCM}$ & $A D$ & ANKRD1 & CARP \\
\hline $\mathrm{DCM} / \mathrm{RCM}$ & $A D$ & $D E S$ & Desmin \\
\hline DCM/LVNC & $A D$ & $\angle M N A$ & Lamin $\mathrm{A} / \mathrm{C}$ \\
\hline DCM & $A D$ & $S A G D$ & $\delta$-sarcoglycan \\
\hline DCM & $A D$ & ACTN2 & $\alpha$-actinin-2 \\
\hline DCM/LVNC & $A D$ & $\angle D B 3$ & Cypher, ZASP, oracle \\
\hline $\mathrm{DCM} / \mathrm{HCM}$ & $A D$ & $P L B$ & Phospholamban \\
\hline DCM & $A D$ & $A B C C 9$ & $\mathrm{~K}_{\text {ATP }}$ channel \\
\hline DCM & $A D$ & SCN5A & Cardiac Na channel \\
\hline $\mathrm{DCM} / \mathrm{HCM}$ & $A D$ & CRYAB & $\alpha \mathrm{B}$ crystallin \\
\hline DCM & $A D$ & PSEN1 & Presenilin-1 \\
\hline DCM & $A D$ & PSEN2 & Presenilin-2 \\
\hline DCM & $A D$ & FHL2 & Four and half LIM protein-2, FHL2 \\
\hline DCM & $A D$ & LMNA4 & Laminin $\alpha 4$ \\
\hline DCM & $A D$ & $I L K$ & Integrin-linked kinase \\
\hline DCM & $A D$ & MYPN & Myopalladin \\
\hline DCM & $A D$ & CHRM2 & Acetylcholine receptor \\
\hline DCM & $\mathrm{XR}$ & $D M D$ & Dystrophin \\
\hline DCM & $\mathrm{XR}$ & $E M D$ & Emerin \\
\hline LVNC/DCM & $\mathrm{XR}$ & $T A Z$ & Tafazzin, G4.5 \\
\hline DCM & $\mathrm{XR}$ & FKTN & Fuktin \\
\hline ARVC/DCM & AR & $D S P$ & Desmoplakin \\
\hline ARVC/DCM & $A R, A D$ & $J U P$ & Plakoglobin \\
\hline ARVC & $A D$ & PKP2 & Plakophilin-2 \\
\hline ARVC & $A D$ & TGFB3 & TGF $\beta 3$ \\
\hline ARVC & $A D$ & $R Y R 2$ & Ryanodine receptor 2 \\
\hline ARVC & $A D$ & DSG3 & Desmoglein 3 \\
\hline LVNC & $A D$ & DTNA & $\alpha$-dystrobrebin \\
\hline
\end{tabular}

Abbreviations: $A D$, autosomal dominant; $A R$, autosomal recessive; DCM, dilated cardiomyopathy; HCM, hypertrophic cardiomyopathy; LVNC, left ventricular noncompaction; RCM, restrictive cardiomyopathy; XR, X-linked recessive.

Gly716Arg and Asp778Gly, with poor survival prognosis ${ }^{14,15}$ were all categorized into charge altered mutation. On the other hand, there were three other different MYH7 mutations, Arg143Gln, Arg870His and Arg870Cys, with relatively benign survival prognosis ${ }^{16,17}$ and two of them, Arg143Gln and Arg870Cys, were also associated with charge alteration. As Arg249Gln, Gly716Arg and Asp778Gly were mapped within the functionally important domain of myosin heavy chain, 
Table 2 Frequencies of disease-associated mutations in Japanese and Korean patients with HCM

\begin{tabular}{lcc}
\hline Gene symbol & Familial case $(\%)(\mathrm{n}=162)$ & Sporadic case $(\%)(\mathrm{n}=100)$ \\
\hline MYH7 & 19.1 & 2.0 \\
TNNT2 & 11.7 & 3.0 \\
TPM1 & 0.6 & 0.0 \\
MYBPC3 & 11.1 & 5.0 \\
MYL3 & 0.6 & 1.0 \\
MYL2 & 1.2 & 0.0 \\
TNNI3 & 2.5 & 3.0 \\
ACTC & 0.0 & 0.0 \\
TTN & $>2.5$ & 2.0 \\
CSRP3 & 0.0 & 0.0 \\
TNNC1 & 0.0 & 0.0 \\
CAV3 & 0.6 & 0.0 \\
MYH6 & $\mathrm{nt}$ & $\mathrm{nt}$ \\
TCAP & 1.2 & 0.0 \\
CRYAB & 0.0 & 0.0 \\
VCL & 0.0 & 0.0 \\
JPH-2 & $\mathrm{nt}$ & $\mathrm{nt}$ \\
MYPN & 0.0 & $\mathrm{nt}$ \\
OBSCN & 0.6 & 0.0 \\
ANKRD1 & 0.6 & 0.0 \\
Sum & $>54.8$ & 15.0 \\
\hline ABI & &
\end{tabular}

Abbreviations: DCM, dilated cardiomyopathy; $\mathrm{HCM}$, hypertrophic cardiomyopathy; nt, not tested. aZ-disc, N2-B, N2-A, Novex3 and is2 domains (about $20 \%$ of entire TTM) were analyzed.

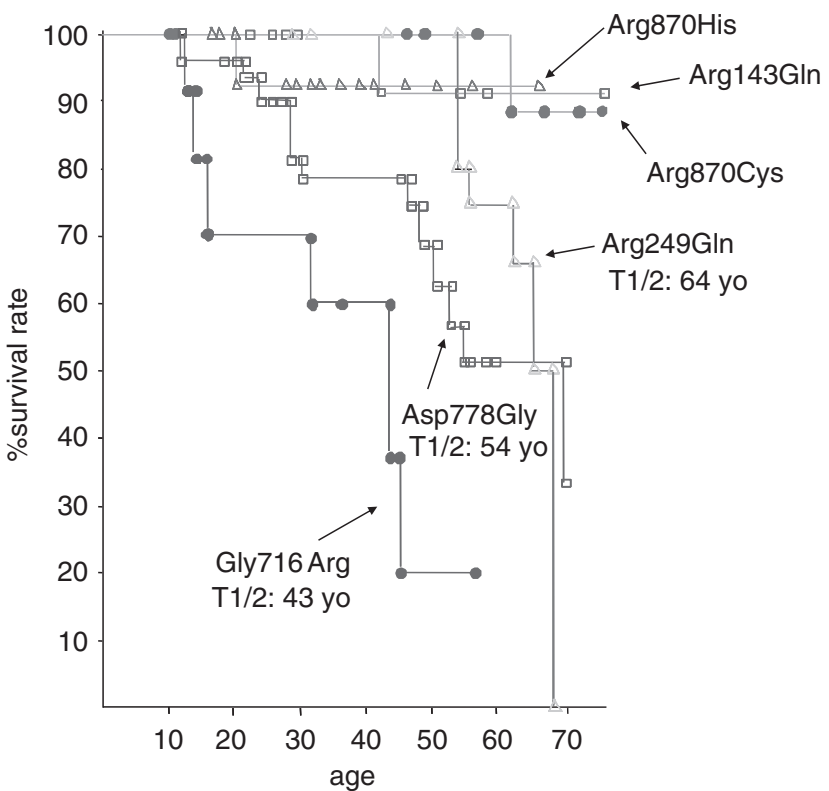

Figure 1 Survival prognosis of $\mathrm{HCM}$ patients with different MYH7 mutations. Cumulative survival of $\mathrm{HCM}$ patients with MHY7 mutations are demonstrated. Arg249GIn, Gly716Arg and Asp778Gly were associated with relatively poor prognosis, whereas Arg143GIn, Arg870His and Arg870Cys showed relatively benign prognosis.

ATP-binding domain, converter domain and myosin light chaininteracting domain, ${ }^{18}$ respectively, while the benign mutations Arg143Gln and Arg870Cys were not mapped within these important domains. As the mutations reported by Watkins et al. ${ }^{13}$ were all
Table 3 Phenotype of HCM patients carrying mutations in $\mathrm{MYH7}$, TNNT2 and MYBPC3

\begin{tabular}{|c|c|c|c|}
\hline & $\begin{array}{c}\text { MYH7 } \\
\text { mutation }\end{array}$ & $\begin{array}{c}\text { TNNT2 } \\
\text { mutation }\end{array}$ & $\begin{array}{l}\text { MYBPC3 } \\
\text { mutation }\end{array}$ \\
\hline Number of patients & 41 & 30 & 41 \\
\hline Number of mutations & 16 & 5 & 9 \\
\hline IVS (mm) & $19.3 \pm 7.6$ & $15.9 \pm 5.0$ & $18.0 \pm 5.7$ \\
\hline $\mathrm{PW}(\mathrm{mm})$ & $11.1 \pm 2.6$ & $10.3 \pm 5.0$ & $11.0 \pm 3.0$ \\
\hline LVDd (mm) & $44.0 \pm 8.4$ & $49.7 \pm 9.9$ & $44.2 \pm 8.2$ \\
\hline LAD (mm) & $40.8 \pm 9.4$ & $40.6 \pm 10.3$ & $38.7 \pm 7.9$ \\
\hline FS (\%) & $37.7 \pm 11.1$ & $30.3 \pm 9.1$ & $35.7 \pm 11.1$ \\
\hline $\mathrm{EF}(\%)$ & $73.5 \pm 14.0$ & $64.3 \pm 14.9$ & $71.2 \pm 14.2$ \\
\hline Age at diagnosis (years) & $36.5 \pm 18.7$ & $41.2 \pm 17.6$ & $39.7 \pm 15.8$ \\
\hline Duration of follow-up (years) & $10.0 \pm 8.0$ & $11.2 \pm 5.7$ & $7.7 \pm 6.2$ \\
\hline \multicolumn{4}{|l|}{ Prognosis of patients (\%) } \\
\hline Improved & 0.0 & 3.3 & 0.0 \\
\hline No change & 59.5 & 25.0 & 64.1 \\
\hline Worse & 24.3 & 42.9 & 28.2 \\
\hline Death & 16.2 & 28.6 & 7.7 \\
\hline Worse+death & 40.5 & 71.4 & 35.9 \\
\hline Rate of death (\% per year) & 1.5 & 2.5 & 1.1 \\
\hline
\end{tabular}

Abbreviations: EF, ejection fraction; FS, fractional shortening; IVS, thickness of intraventricular septum; LAD, left atrial dimension; LVDd, diastolic left ventricular dimension; PW, thickness of posterior ventricular free wall.

mapped within the ATP-binding domain, actin-interacting domain, converter domain or myosin light chain-interacting domains, ${ }^{18}$ it was speculated that the mutations with charge alteration and mapped within the functionally important domains were correlated with poor survival prognosis.

In addition, there were several interesting characteristics of mutation-prone HCM patients in East Asians (Japanese and Korean), such that cardiac hypertrophy was more prominent in $M Y H 7$ and MYBPC3 cases than TNNT2 cases (Table 3). It may be worth noting that the age at diagnosis was relatively late and cardiac function at the diagnosis was relatively lowered in TNNT2 cases than the others. ${ }^{10}$ This was in good agreement with that TNNT2 mutations are generally associated with poor prognosis and sudden cardiac death in European populations. ${ }^{19,20}$ Although MYBPC3 cases were initially reported to follow relatively benign clinical course in an European population, ${ }^{21}$ our data showed that $36 \%$ of $M Y B P C 3$ cases in East Asians followed worse prognosis during the follow-up period (Table 3). In general, cardiac hypertrophy developed at the diagnosis gradually reduced during the follow-up period, and cardiac function becomes decreased later in the life even in the MYBPC3 cases. $^{22}$

Initial analysis of functional changes caused by the MYH7 mutations demonstrated decreased power generation by the mutant myosin heavy chains ${ }^{23}$ and the identification of HCM-related mutations in sarcomere components, troponin $\mathrm{T}$ and $\alpha$-tropomyosin, had lead to a hypothesis that HCM is the disease of sarcomere and the cardiac hypertrophy was a compensation of decreased power generation. ${ }^{24}$ However, we found HCM-associated TNNI3 mutations at the contraction inhibitory domain, ${ }^{10}$ which implied that the decreased power was not a common functional change caused by the sarcomere mutations. Indeed, subsequent functional analyses of mutations in genes for other sarcomere components than MTH7 have revealed that contractile performance was not decreased by the mutations and most $\mathrm{HCM}$-associated sarcomere mutations resulted in increased $\mathrm{Ca}^{2+}$ sensitivity of muscle contraction. ${ }^{25-30}$ As an $M Y H 7$ mutation that 
caused HCM in transgenic mice also increased $\mathrm{Ca}^{2+}$ sensitivity at the muscle fiber level, ${ }^{31}$ a common functional alteration caused by HCMrelated sarcomere mutations may be the increased $\mathrm{Ca}^{2+}$ sensitivity. Muscle contraction is regulated by the concentration of intracellular $\mathrm{Ca}^{2+}$ that is released from sarcoplasmic reticulum (SR) via ryanodine receptor (RyR2) and re-up taken to SR via SR $\mathrm{Ca}^{2+}$-ATPase (SERCA). When the concentration of $\mathrm{Ca}^{2+}$ is increased or decreased, muscle is contracted or relaxed, respectively. Increased $\mathrm{Ca}^{2+}$ sensitivity is a leftward shift of $\mathrm{Ca}^{2+}$-tension curve; more tension is generated by mutant sarcomere than normal sarcomere at the same $\mathrm{Ca}^{2+}$ concentration (hypercontraction) or muscle with mutant sarcomere is under less relax states (diastolic dysfunction) than normal sarcomere. This is consistent with the finding that characteristic features of HCM are hypercontraction and diastolic dysfunction.

\section{Z-DISC MUTATIONS IN HCM}

As mutations in the sarcomere components were found in only less than half of familial HCM patients, there should be other disease gene(s) for HCM, and candidate gene approaches were taken to identify the disease-related mutations in other genes expressed in cardiac muscle (Figure 2). Identification of an HCM-associated mutation in titin gene $(T T N)$ was the first example of disease gene other than the sarcomere components, ${ }^{32}$ and the functional alteration due to the TTN mutation was an increased binding to $\alpha$-actinin (Figure 3). In addition, we demonstrated that the HCM-associated Tcap gene (TCAP) mutations increased the binding of Tcap to titin, MLP and carsarcin- $1,{ }^{33}$ leading to a hypothesis that Z-disc mutations in HCM may result in increased binding of Z-disc components and hence 'stiff sarcomere' (Figure 3). 'Stiff sarcomere' would increase passive tension on stretch of sarcomere. As the increased passive tension was associated with increased $\mathrm{Ca}^{2+}$ sensitivity, ${ }^{34-36}$ we have speculated that HCM-associated abnormality in both Z-disc components and sarcomere components cause the increased $\mathrm{Ca}^{2+}$ sensitivity. It should be noted that a possible controversy exists; that is, HCMassociated MLP gene (CSRP3) mutations were reported to decrease the binding to $\alpha$-actinin and N-RAP. ${ }^{37,38}$ However, as discussed in the later section, DCM-associated mutations were found in CSRP3 and $\alpha$-actinin gene (ACTN2), and these mutations decreased binding to each other. ${ }^{39}$ Therefore, the decreased binding between MLP and $\alpha$ actinin was associated with both HCM and DCM. This discrepancy should be resolved by further studies.

\section{OTHER MUTATIONS IN HCM}

There are several other disease genes for HCM, including mutations in caveolin-3 gene $(C A V 3),{ }^{40}$ meta-vinculin gene $(V C L),{ }^{41} \alpha \mathrm{B}$-crystallin gene $(C R Y A B),{ }^{42}$ junctophilin-2 gene $(J P H-2),{ }^{43}$ obscurin gene $(\mathrm{OBSCN})^{44}$ and most recently reported CARP gene $(A N K R D 1)^{45}$ (Figure 2). Functional analyses were reported for CRYAB, CAV3, OBSCN and ANKRD1 mutations; aggregation of $\alpha \mathrm{B}$-crystalline in cytoplasm, ${ }^{42}$ decreased cell surface expression of caveolin- $3,{ }^{40}$ decreased binding to titin, ${ }^{44}$ and increased binding to titin and myopalladin, ${ }^{45}$ respectively. It is not clear how the aggregated $\alpha \mathrm{B}$-crystalline resulted in cardiac hypertrophy, but impaired stress response may exaggerate hypertrophic response. ${ }^{46}$ It should be noted here that an HCM-associated TTN mutation in N2B region increased binding to FHL2 protein ${ }^{47}$ and decreased binding to $\alpha \mathrm{B}$-crystalline. ${ }^{48}$ As for the function of caveolin-3 in cardiac function, it was reported that cell surface expression of caveolin-3 was associated with cardiac hypertrophy. ${ }^{49}$ It was also reported that overexpression of caveolin-3 inhibit the hypertrophic response, ${ }^{50}$ suggesting that reduced caveolin3-mediated signaling would result in cardiac hypertrophy. Function of obscurin is not fully understood, but obscurin may be involved in calmodulin/CaMK-mediated signaling because obscurin was reported to bind and tether calmodulin to titin, ${ }^{51}$ of which process was impaired by the HCM-associated OBSCN mutation. The functional significance of increased binding of CARP to titin and myopalladin caused by the ANKRD1 mutations is not clarified, but mutant CARP showed nuclear or peri-nuclear localization, whereas normal CARP was exclusively localized in the cytoplasm. ${ }^{52}$ As CARP is a hypertrophy-related transcriptional co-factor ${ }^{52}$ and is known to be localized

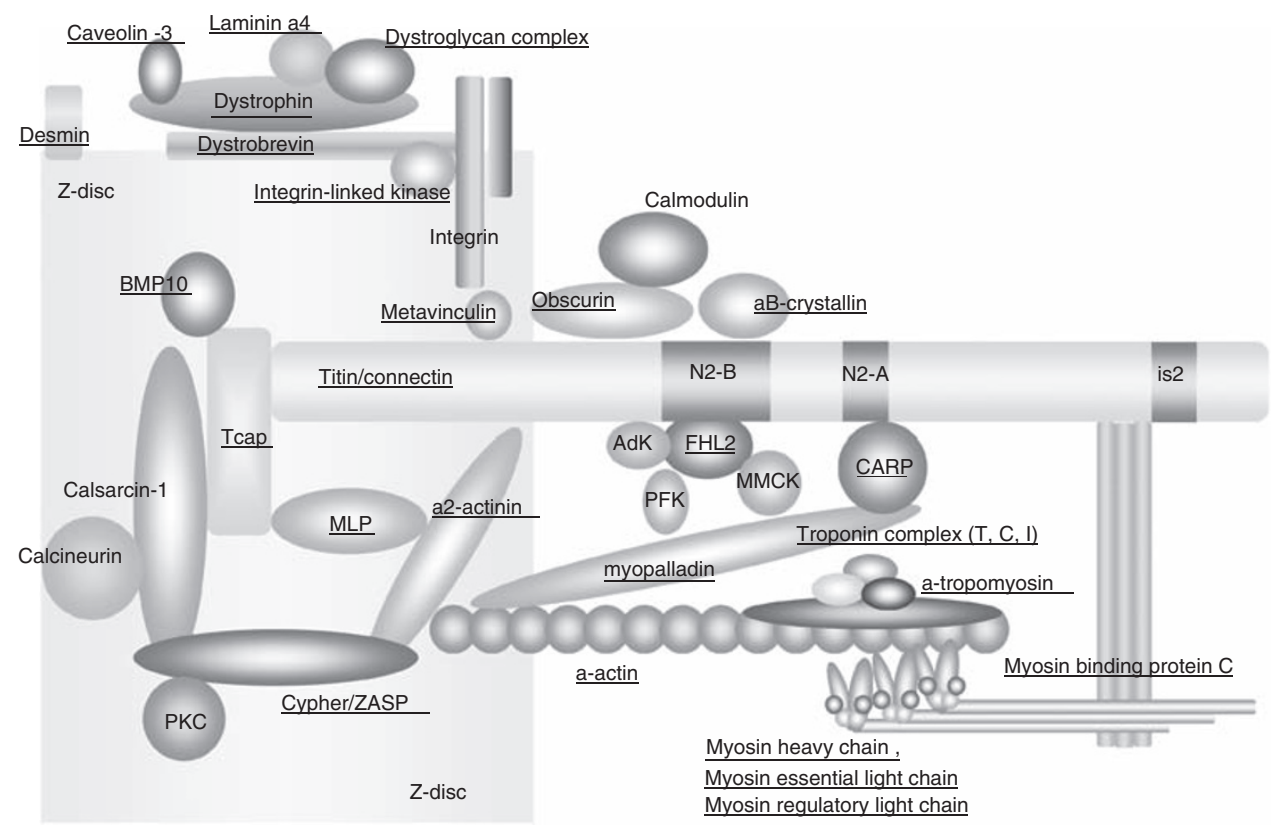

Figure 2 Schematic representation of sarcomere components. Half sarcomere is schematically shown. Components in which cardiomyopathy-associated mutations are found are underlined. 


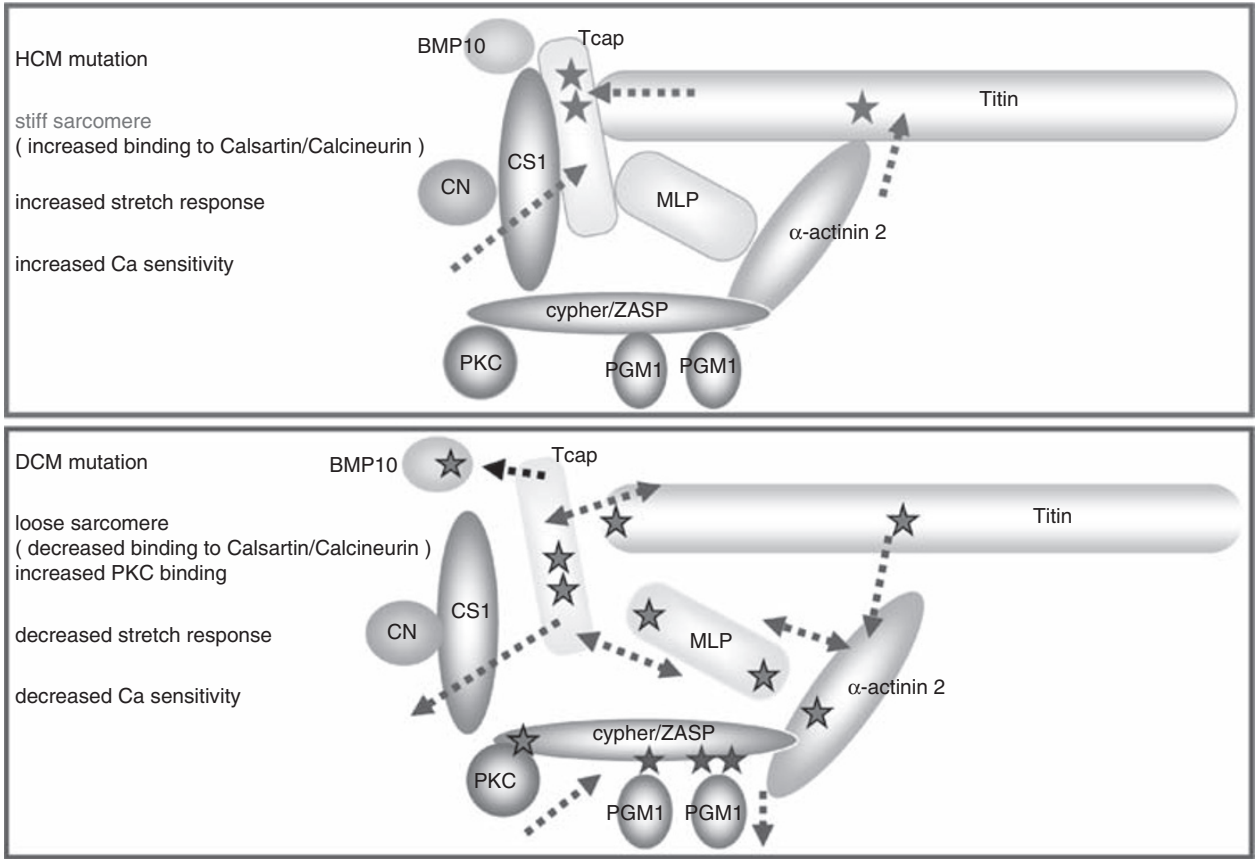

Figure 3 Schematic representation of functional alterations caused by Z-disc mutations. Functional alterations found with HCM-associated mutations (red stars) are shown in the upper panel, whereas the lower panel indicated the functional changes caused by DCM-associated mutations (blue stars). Broken arrows show the altered interactions caused by the mutations. CN, calcineurin; CS1, calsarcin-1. A full color version of this figure is available at the Journal of Human Genetics journal online.

in the cytoplasm and shifted to nucleus when cardiomyocytes were stretched, ${ }^{53}$ presence of mutant CARP to nucleus suggested that the mutation rendered the cardiomyocytes hypersensitive to the stretch response leading to hypertrophy.

\section{MEMBRANOUS AND CYTOSKELETAL MUTATIONS IN DCM}

The first discovery of disease gene for DCM is a mutation in dystrophin gene $(D M D)$ found in male siblings of X-linked DCM. ${ }^{54}$ $\mathrm{X}$-linked DCM is a rare form of familial DCM almost exclusively affecting males. ${ }^{55} \mathrm{DMD}$ mutations are known to cause Duchenne type and Becker type muscular dystrophy. In general, muscular dystrophy mainly affects skeletal muscles, and cardiac involvement is observed usually later in the clinical course. ${ }^{56,57}$ However, X-linked DCM cases usually manifest with cardiac symptoms and subtle skeletal muscle involvement, ${ }^{55}$ and phenotypic variance of $D M D$ mutation may be caused by which domain of dystrophin was affected. ${ }^{56}$ As shown in Table 4, our study showed that DMD mutations could be found in 5\% of sporadic cases. None of these patients showed skeletal muscle symptoms, demonstrating that X-linked DCM should be considered not only for male sibling of familial DCM but also for male cases of sporadic DCM.

Dystrophin is a membranous protein having an important function in mechanical links from extracellular matrix to intracellular cytoskeleton in association with other proteins forming dystroglycan complex (DGC) ${ }^{58}$ As muscle contraction forces myocytes with deformity and shortening/stretching, myofilaments should be tightly anchored to membrane and extracellular matrix via DGC to properly transmit the force with avoiding damages of cell membrane. Components of DGC in skeletal and cardiac muscles include dystrophin, dystroglycans $(\alpha$ and $\beta$ ), laminin $\alpha$ s, sarcoglycans $(\alpha, \beta, \gamma$ and $\delta$ ), dystrobrebins ( $\alpha$ and $\beta$ ), syntrophin and caveolin-3. In addition to DGC, integrins ( $\alpha$ and $\beta$ ) are concentrated at the costemeres that overly Z-lines in striated muscles, and the integrin complex also has a function in mechanical
Table 4 Frequencies of disease-associated mutations in Japanese and Korean adult patients with DCM

\begin{tabular}{|c|c|c|}
\hline Gene symbol & Familial case $(\%)(\mathrm{n}=48)$ & Sporadic case $(\%)(\mathrm{n}=100)$ \\
\hline ACTC & 0.0 & 0.0 \\
\hline$D E S$ & 2.1 & 0.0 \\
\hline$D M D$ & 0.0 & 5.0 \\
\hline LMNA & 0.0 & nt \\
\hline$S A G D$ & 0.0 & nt \\
\hline MYH7 & 0.0 & 0.0 \\
\hline TNNT2 & 0.0 & 0.0 \\
\hline TPM1 & 0.0 & 0.0 \\
\hline$T T N^{a}$ & $>6.3$ & $>2.0$ \\
\hline CSRP3 & 0.0 & 0.0 \\
\hline$V C L$ & 0.0 & 0.0 \\
\hline CRYAB & 2.1 & 0.0 \\
\hline МYВРC3 & 0.0 & 0.0 \\
\hline TCAP & 2.1 & 0.0 \\
\hline ACTN2 & 0.0 & 0.0 \\
\hline$\angle D B 3$ & 2.1 & 0.0 \\
\hline FKTN & 0.0 & 0.0 \\
\hline FHL2 & 2.1 & 0.0 \\
\hline PDLIM3 & nt & nt \\
\hline$M Y P N$ & 0.0 & 0.0 \\
\hline LMNA4 & 0.0 & 0.0 \\
\hline$I L K$ & 0.0 & 0.0 \\
\hline$A N K R D 1$ & 0.0 & 0.0 \\
\hline Sum & $>16.7$ & $>7.0$ \\
\hline
\end{tabular}

Abbreviations: DCM, dilated cardiomyopathy; nt, not tested.

aZ-disc, N2-B, N2-A, Novex3 and is2 domains (about $20 \%$ of entire TTN) were analyzed.

links of power transmission. ${ }^{58}$ Therefore, abnormalities in DGC and integrin complex may result in muscular dystrophy and cardiomyopathy. Indeed, mutations in $\delta$-sarcoglycan gene $(S A G D),{ }^{59}$ 
laminin $\alpha 4$ gene $(L M N A 4),{ }^{60}$ and integrin-linked kinase gene $(I L K)^{60}$ were found to cause DCM of autosomal dominant inheritance (Table 1). It was proposed that DCM was the disease of cytoskeleton or its interacting proteins. ${ }^{61}$ However, recent studies showed that etiology of DCM is not confined to the abnormality of the cytoskeleton-related proteins.

\section{SARCOMERE MUTATIONS IN DCM}

Identification of cardiac $\alpha$-actin gene (CACT) mutations was the first discovery of genetic cause of autosomal dominant DCM. ${ }^{62}$ In addition, CACT mutation was also found in $\mathrm{HCM}^{63}{ }^{63}$ demonstrating that sarcomere mutations cause both HCM and DCM; that is, overlapping disease genes for different cardiomyopathy. Molecular basis of different phenotypes caused by CACT mutations was suggested that DCMassociated mutations were found at the $\alpha$-actinin-interacting domain, ${ }^{62}$ whereas HCM-associated mutations were at the interacting domain to myosin heavy chain. ${ }^{63}$ On the other hand, recent data suggested that there is a difference in folding property between the DCM-associated mutant actin and HCM-associated mutant actin. ${ }^{64}$ Another example of overlapping disease gene was the identification of TNNT2 mutation in DCM. ${ }^{65}$ Functional study of TNNT2 mutations clearly demonstrated the difference between DCM-associated mutation and HCM-associated mutation; that is, DCM-associated TNNT2 mutation decreased $\mathrm{Ca}^{2+}$ sensitivity of muscle contraction, which is in clear contrast to the increased sensitivity caused by the HCMassociated mutation. ${ }^{66}$ Therefore, sarcomere mutations can be found in both HCM and DCM, but difference in the functional alterations may determine the different phenotypes. ${ }^{67}$

\section{Z-DISC MUTATIONS IN DCM}

Mutations of membranous, cytoskeletal or sarcomere components were not found in our panel of familial DCM, whereas mutations in Z-disc components were relatively frequent (Table 4 ). We have reported several DCM-associated Z-disc protein gene mutations in TTN, ${ }^{68}$ CSRP $3,{ }^{69}$ TCAP $^{33,69}$ and Cypher/ZASP gene $(L D B 3),{ }^{70}$ albeit that CSRP3 mutation was not found in Japanese or Korean patients. ${ }^{69}$ As described in the HCM section, the DCM-associated TCAP mutations showed opposite functional alterations to the HCM-associated mutations. ${ }^{33}$ Similarly, a DCM-associated TTN mutation found in the actinin-binding domain showed decreased binding to actinin. ${ }^{68}$ In addition, another DCM-associated TTN mutation found in the Tcapbinding domain decreased the binding to Tcap. ${ }^{68}$ As the Z-disc element mutations result in decreased binding among the elements, we hypothesize that DCM is the disease of 'loose sarcomere'12,33 (Figure 3). The loose sarcomere is evident in an animal model of DCM, CSRP3 (MLP) knock-out mouse, in which Z-disc was wide and stretch response was impaired. ${ }^{69}$ As the stretch response is a hypertrophic response of cardiomyocytes against passive tension and Z-disc elements is suggested to be a stretch sensor of cardiomyocytes, abnormality in Z-disc elements may alter the regulation of stretch response.

Cypher/ZASP is a Z-disc element connecting calsarcin and acti$\operatorname{nin} .{ }^{70}$ It is interesting to note that calsarcin binds calcineurin, ${ }^{71}$ a Ser/ Thr phosphatase involved in the process of hypertrophic program of cardiomyocytes. ${ }^{72,73}$ Functional significance of calcineurin anchorage to Z-disc is not fully understood, but it was involved in stress-induced calcineurin-NFAT activation, because heterozygous MLP knock-out mice showed reduction in NFAT activation along with dislocation of calcineurin from Z-disk. ${ }^{74}$ On the other hand, Cypher/ZASP binds protein kinase $\mathrm{C}(\mathrm{PKC})^{70}$ and a DCM-associated $L D B 3$ mutation in the PKC-binding domain was found to increase the binding, ${ }^{75}$ it was suggested that phosphorylation/dephosphorylation of Z-disc elements might be involved in the stretch response. Identification of target protein(s) for phosphorylation (by PKC)/dephosphorylation (by calcineurin) will unravel the molecular mechanism(s) of stretch response and/or signaling molecule(s) of cardiac hypertrophy.

Several other $L D B 3$ mutations not in the PKC-interacting domain were reported in DCM or LVNC. ${ }^{76}$ As the functional changes caused by these mutations had not been demonstrated, we have searched for binding protein to Cypher/ZASP by using yeast two-hybrid method, and found that phosphoglucomutase-1 (PGM1) as a novel-binding protein. ${ }^{77}$ PGM1 is an enzyme involved in the conversion between glucose-6-phospate and glucose-1-phosphate, which is involved in the glucose/glycogen metabolism. Functional significance of the binding between PGM1 and the Z-disc element Cypher/ZASP was not known, but the DCM-associated mutations reported by Vatta et al. ${ }^{76}$ showed decreased binding to PGM1. ${ }^{77}$ In addition, PGM1 was demonstrated to be localized at the Z-disc under the stressed culture conditions, low serum and low glucose, suggesting the role of PGM1 in the energy metabolism at the Z-disc. ${ }^{77}$ These observations suggested that the decreased stress response might be involved in the pathogenesis of DCM.

There are other DCM-associated mutations found in genes for other Z-line associated proteins, desmin $(D E S)^{78}$ and metavinculin (VCL). ${ }^{79}$ The VCL mutation was showed to impair the binding to actin, ${ }^{79}$ whereas the DES mutations resulted in subtle change in the cytoplasmic DES network. ${ }^{80}$ In addition, mutations in myopalladin gene $(M Y P N)$ have recently been reported in DCM. Although the molecular mechanisms of MYPN mutations leading to DCM remained unclear, the DCM-associated mutations impaired the myofiblinogenesis. ${ }^{81}$

\section{OTHER MUTATIONS IN DCM}

Etiology of familial DCM is quite heterogeneous, and there are several other disease genes for DCM categorized into several groups. The first group includes mutations in genes for nuclear membrane proteins, lamin A/C $(L M N A)^{82,83}$ and emerin $(E M D),{ }^{84}$ which cause autosomal dominant and $\mathrm{X}$-linked Emery-Dreifuss muscular dystrophy (EDMD), respectively. EDMD manifests with muscular dystrophy and DCM associated with conduction block. ${ }^{85}$ Molecular mechanisms underlying the development of DCM caused by the nuclear membrane abnormality remain not fully understood, ${ }^{86}$ but a study of an LMNA mutation knock-in mouse ${ }^{87}$ showed that the mutation activated the MAPK pathway, suggesting an impaired signal transduction was involved in the pathogenesis of DCM. ${ }^{88}$

The second group consists of mutations affecting ion channel function; regulatory subunit of ATP-sensitive potassium channel $(A B C C 9)^{89}$ and cardiac sodium channel $(S C N 5 A) .{ }^{90}$ Clinical phenotypes of $A B C C 9$ and $S C N 5 A$ mutations were DCM accompanied by ventricular tachyrcardia ${ }^{89}$ and conduction defects, ${ }^{90}$ respectively. It should be noted here that the channelopathy is etiologically overlapping with the cardiomyopathy, such as SCN5A mutations in DCM and long QT syndrome, CAV3 mutations in HCM and long QT syndrome, and RYR2 mutations in ARVC and catecholaminergic polymorphic ventricular tachycardia. ${ }^{91}$

The third group is composed of mutations in genes for titin-N2Binteracting proteins, four and half LIM protein $(F H L 2)^{92}$ and $\alpha \mathrm{B}-$ crystallin $(C R Y A B) .{ }^{48}$ As a titin-N2B region mutation found in DCM reduced binding to $\mathrm{FHL} 2^{47}$ and an FHL2 mutation reduced binding to titin-N2B, ${ }^{92}$ impaired interaction between titin and FHL2 appeared as a result in DCM. Molecular mechanisms underlying this phenomenon may be that FHL2 function as a tethering molecule of adenyl kinase, 
phosphofructokinase and muscle creatine kinase; that is, proper recruitment of metabolic enzymes was impaired, although abnormality in other functions of FHL2 ${ }^{93}$ could not be neglected. The DCMassociated $C R Y A B$ mutation decreased binding to titin-N2B region and a DCM-associated titin-N2B region mutation decreased binding to $\alpha \mathrm{B}$-crystallin, ${ }^{48}$ suggesting that impaired interaction between titin$\mathrm{N} 2 \mathrm{~B}$ and $\alpha \mathrm{B}$-crystallin resulted in DCM. However, an HCM-associated titin-N2B mutation also reduced the binding to $\alpha \mathrm{B}$-crystallin, ${ }^{47}$ and it is not clear why the impaired binding of titin-N2B and $\alpha \mathrm{B}-$ crystallin could express as both HCM and DCM. There may be additional factors involved in the phenotypic expression of titinN2B mutations, such that binding to FHL2 was different between the HCM- and DCM-associated mutations and that the DCMassociated titin-N2B mutation was a truncation mutation, whereas the $\mathrm{HCM}$-associated mutation was a missense mutation. ${ }^{47} \mathrm{In}$ addition, we found DCM-associated mutations in ANKRD $1 .{ }^{94}$

The fourth group is related to intracellular $\mathrm{Ca}^{2+}$ handling. As muscle contraction is depending on the $\mathrm{Ca}^{2+}$ concentration, SERCA function in re-uptaking the intracellular $\mathrm{Ca}^{2+}$ to SR leads to relaxation of muscle. Phospolamban is an inhibitory molecule of SERCA, which is physiologically active when phosphorylated by protein kinase A (PKA). ${ }^{95}$ Functional analysis of phospholamban gene (PLN) mutations found in DCM showed that the mutation was constitutive active; that is, inhibiting SERCA. ${ }^{96,97}$ In contrast, a truncation mutation of $P L N$, that is loss of PLN function, is recently reported in familial HCM $^{98}$ Although PLN deficiency in mice resulted in enhanced contractility, ${ }^{99}$ no cardiac hypertrophy was observed in the mice. In addition, loss of PLN rescued DCM phenotype ${ }^{100}$ in MLP knock-out mice, and a dominant-negative form of PLN prevented heart failure in cardiomyopathic hamster BIO14.6, ${ }^{101}$ which is known to be caused by $S A G D$ deficiency. ${ }^{102}$ These observations suggest that functional impairment of phospholamban may prevent systolic dysfunction but not directly involved in the cardiac hypertrophy. Moreover, promoter mutations of PLN, which increased transcription, were recently reported in HCM. ${ }^{103,104}$ As transgenic mice over-expressing PLN did not show cardiac hypertrophy, rather they showed systolic dysfunction, ${ }^{105}$ pathological significance of PLN promoter mutations in HCM remains to be clarified.

The other mutations found in DCM include G4.5 gene (tafazzin, TAZ, Barth's syndrome), ${ }^{106}$ fukutin gene (FKTN), ${ }^{107}$ desmoplakin gene $(D S P),{ }^{108}$ plakoglobin gene $(J U P)^{109}$ mutations. These mutations, however, were not found in 'pure' DCM and found in 'syndromic' DCM that is accompanied by disorders and/or dysfunction in skeletal muscle, skin or hair. An example is that FKTN mutation was not found in pure DCM, but was found in skeletal myopathy accompanied by DCM and an early sign of FKTN mutation-associated DCM was hyper-CKemia. ${ }^{110}$

\section{MUTATIONS IN OTHER CARDIOMYOPATHIES}

Disease-causing gene mutations can also be identified in other cardiomyopathies. As shown in Table 1, mutations in sarcomere proteins were found in RCM. It is interesting to note that $M Y H 7$, TNNT2 and TNNI3 mutations were associated with RCM, HCM and DCM. Molecular basis of the differences between RCM-associated mutations and HCM-associated mutations was that the RCM-associated mutations showed much greater $\mathrm{Ca}^{2+}$ sensitization than the HCM-associated mutations, as demonstrated for TNNT2 ${ }^{111}$ and TNNI3 ${ }^{112}$ mutations. In accordance with these findings, it was reported that restrictive phenotype (RCM-like HCM) was uncommon in $\mathrm{HCM}$ and may represent a poor prognosis form with severe diastolic dysfunction. ${ }^{113}$ On the other hand, the difference between
RCM-associated mutations and DCM-associated mutations is not clear, but a gene-dose effect could be involved in the difference because RCM-associated TNNI3 mutation was found in heterozygous state, ${ }^{114}$ whereas the DCM-associated TNNI3 mutation was found in homozygous state. ${ }^{115}$

LVNC is a recently described cardiomyopathy where ventricular trabeculations was poorly developed, and mutations in $M Y H 7,116$ CACT, ${ }^{117}$ DES, ${ }^{78}$ LMNA, ${ }^{118}$ TAZ, ${ }^{119}$ DTNA, ${ }^{120}$ and ${ }^{10}$ BB3 ${ }^{76}$ were reported in LVNC (Table 1). Molecular mechanisms of the mutations in causing LVNC are not elucidated. In a mouse model, deficiency of BMP10 resulted in LVNC phenotype. ${ }^{121}$ BMP10 is a member of TGF $\beta$ family, which is expressed mainly in the heart, and has an important function in morphogenesis of the heart. ${ }^{122}$ Therefore, LVNC might be a developmental error in the hearts carrying the mutations in components of sarcomere and/or sarcolemma. Interestingly, a rare polymorphism of BMP10 gene was found in hypertensive DCM, which decreased binding to Tcap and increased extracellular secretion of BMP10 facilitating the remodeling of hypertensive hearts. ${ }^{123}$

Another primary cardiomyopathy AVRC has also been investigated for disease-causing mutations ${ }^{124}$ (Table 1). As the ARVC-associated mutations can be found in genes for plakoglobin (JUP), ${ }^{125}$ desmoplakin $(D S P),{ }^{126}$ plakophilin-2 (PKP2) ${ }^{127}$ and desmoglein (DSG3), ${ }^{128}$ they were considered to disrupt cell-cell contacts via desmosomes. RYR2 mutations were also reported in ARVC, ${ }^{129}$ linking cardiomyopathy to channelopathy. Promoter variant of TGF $\beta 3$ was also reported in ARVC, ${ }^{130}$ but its pathological significance remains to be resolved.

\section{CONCLUSION}

In this review, gene mutations found in the hereditary cardiomyopathy are summarized. Each family or patient has usually only one disease-causing mutation, but the primary cardiomyopathy is both clinically and etiologically heterogeneous even in a specific clinical type (HCM, DCM, RCM, ARVC and LVNC). As different causes result in the same phenotype, there may be several pathways in the pathogenesis of primary cardiomyopathy, such as abnormalities in the $\mathrm{Ca}^{2+}$ sensitivity, stretch response, stress response and others. Intervention of these common pathways will be a therapeutic or preventive strategy for hereditary cardiomyopathy caused by different mutations. In this respect, it is noteworthy that administration of a $\mathrm{Ca}^{2+}$ sensitizing chemical compound $\mathrm{SCH} 00013^{131}$ prolonged the disease onset, improved the survival prognosis and ameliorated the cardiac remodeling in a DCM model animal, LMNA knock-in mice. ${ }^{132}$

\section{ACKNOWLEDGEMENTS}

This work was supported in part by Grant-in-Aids for Scientific Research from the Ministry of Education, Culture, Sports, Science and Technology, Japan, research grant for Idiopathic Cardiomyopathy from the Ministry of Health, Labor and Welfare, Japan, and grants for Basic Scientific Cooperation Program between Japan and Korea from the Japan Society for the Promotion of Science and the Korea Science and Engineering Foundation.

1 Maron, B. J., Towbin, J. A., Thiene, G., Antzelevitch, C., Corrado, D., Arnett, D. et al. Contemporary definitions and classification of the cardiomyopathies: an American Heart Association Scientific Statement from the Council on Clinical Cardiology, Heart Failure and Transplantation Committee; Quality of Care and Outcomes Research and Functional Genomics and Translational Biology Interdisciplinary Working Groups; and Council on Epidemiology and Prevention. Circulation 113, 1807-1816 (2006).

2 Towbin, J. A. \& Bowles, N. E. The failing heart. Nature 415, 227-233 (2002).

3 Ahmad, F., Seidman, J. G. \& Seidman, C. E. The genetic basis for cardiac remodeling. Annu. Rev. Genomics Hum. Genet. 6, 185-216 (2006).

4 Kushwaha, S. S., Fallon, J. \& Fuster, V. Restrictive cardiomyopathy. N. Engl. J. Med. 336, 267-276 (1997). 
5 Seidman, J. G. \& Seidman, C. The genetic basis for cardiomyopathy: from mutation identification to mechanistic paradigms. Cell 104, 557-567 (2001).

6 Goerss, J. B., Michels, V. V., Burnett, J., Driscoll, D. J., Miller, F., Rodeheffer, R. et al. Frequency of familial dilated cardiomyopathy. Eur. Heart J. 16, 02-04 1995)).

7 Mestroni, L., Rocco, C., Gregori, D., Sinagra, G., Di Lenarda, A., Miocic, S. et al. Familial dilated cardiomyopathy: evidence for genetic and phenotypic heterogeneity. Heart Muscle Disease Study Group. J. Am. Coll. Cardiol. 34, 181-190 (1999).

8 Geisterfer-Lowrance, A. A. T., Kass, S., Tanigawa, G., Vosberg, H. P., McKenna, W., Seidman, C. E. et al. A molecular basis for familial hypertrophic cardiomyopathy: a beta cardiac myosin heavy chain gene missense mutation. Cell 62, 999-1006 (1990).

9 Nishi, H., Kimura, A., Harada, H., Adachi, K., Koga, Y., Sasazuki, T. et al. Possible gene dose effect of a mutant cardiac beta-myosin heavy chain gene on the clinical expression of familial hypertrophic cardiomyopathy. Biochem. Biophys. Res. Commun. 200, 549-556 (1994).

10 Kimura, A., Harada, H., Park, J. E., Nishi, H., Satoh, M., Takahashi, M. et al. Mutations in the cardiac troponin I gene associated with hypertrophic cardiomyopathy. Nature Genet. 16, 379-382 (1997).

11 Arad, M., Seidman, J. G. \& Seidman, C. E. Phenotypic diversity in hypertrophic cardiomyopathy. Hum. Mol. Genet. 11, 2499-2506 (2002).

12 Kimura, A. Molecular etiology and pathogenesis of hereditary cardiomyopathy. Circ. J. 72, A38-A48 (2008).

13 Watkins, H., Rosenzweig, A., Hwang, D. S., Levi, T., McKenna, W. et al. Characteristics and prognostic implications of myosin missense mutations in familial hypertrophic cardiomyopathy. N. Engl. J. Med. 326, 1108-1114 (1992).

14 Harada, H., Kimura, A., Nishi, H., Sasazuki, T. \& Toshima, H. A missense mutation of cardiac beta-myosin heavy chain gene linked to familial hypertrophic cardiomyopathy in affected Japanese families. Biochem. Biophys. Res. Commun. 194, 791-798 (1993).

15 Hwang, T. H., Lee, W. H., Kimura, A., Satoh, M., Nakamura, T., Kim, M. K. et al. Early expression of a malignant phenotype of familial hypertrophic cardiomyopathy associated with a Gly716Arg myosin heavy chain mutation in a Korean family. Am. J. Cardiol. 82, 1509-1513 (1998).

16 Nishi, H., Kimura, A., Harada, H., Koga, Y., Adachi, K., Matsuyama, K., Koyanagi, T. et al. A myosin missense mutation, not a null allele, causes familial hypertrophic cardiomyopathy. Circulation 91, 2911-2915 (1995).

17 Koga, Y., Toshima, H., Kimura, A., Harada, H., Koyanagi, T., Nishi, H. et al. Clinical manifestations of hypertrophic cardiomyopathy with mutations in the cardiac betamyosin heavy chain gene or cardiac troponin T gene. J. Card. Fail. 2, S97-S103 (1996).

18 Rayment, I., Holden, H. M., Sellers, J. R., Fananapazir, L. \& Epstein, N. D. Structural interpretation of the mutations in the beta-cardiac myosin that have been implicated in familial hypertrophic cardiomyopathy. Proc. Natl. Acad. Sci. USA 92, 3864-3868 (1995).

19 Watkins, H., McKenna, W. J., Thierfelder, L., Suk, H. J., Anan, R. et al. Mutations in the genes for cardiac troponin $\mathrm{T}$ and alpha-tropomyosin in hypertrophic cardiomyopathy. N. Engl. J. Med. 332, 1058-1064 (1995).

20 Varnava, A. M., Elliott, P. M., Baboonian, C., Davison, F., Davies, M. J. \& McKenna, W. J. Hypertrophic cardiomyopathy: histopathological features of sudden death in cardiac troponin T disease. Circulation 104, 1380-1384 (2001).

21 Niimura, H., Patton, K. K., McKenna, W. J., Soults, J., Maron, B. J., Seidman, J. G. et al. Sarcomere protein gene mutations in hypertrophic cardiomyopathy of the elderly. Circulation 105, 446-451 (2002).

22 Kubo, T., Kitaoka, H., Okawa, M., Matsumura, Y., Hitomi, N., Yamasaki, N. et al. Lifelong left ventricular remodeling of hypertrophic cardiomyopathy caused by a founder frameshift deletion mutation in the cardiac myosin-binding protein $\mathrm{C}$ gene among Japanese. J. Am. Coll. Cardiol. 46, 1737-1743 (2005).

23 Sweeney, H. L., Straceski, A. J., Leinwand, L. A., Tikunov, B. A. \& Faust, L. Heterologous expression of a cardiomyopathic myosin that is defective in its actin interaction. J. Biol. Chem. 269, 1603-1605 (1994).

24 Thierfelder, L., Watkins, H., MacRae, C., Lamas, R., McKenna, W., Vosberg, H. P. et al. Alpha-tropomyosin and cardiac troponin $\mathrm{T}$ mutations cause familial hypertrophic cardiomyopathy: a disease of the sarcomere. Cell 77, 701-712 (1994).

25 Yanaga, F., Morimoto, S. \& Ohtsuki, I. Ca2+ sensitization and potentiation of the maximum level of myofibrillar ATPase activity caused by mutations of troponin T found in familial hypertrophic cardiomyopathy. J. Biol. Chem. 274, 8806-8812 (1999).

26 Bottinelli, R. Coviello, D. A., Redwood, C. S., Pellegrino, M. A., Maron, B. J., Spirito, P. et al. A mutant tropomyosin that causes hypertrophic cardiomyopathy is expressed in vivo and associated with an increased calcium sensitivity. Circ. Res. 82, 106-115 (1998).

27 Elliott, K., Watkins, H. \& Redwood, C. S. Altered regulatory properties of human cardiac troponin I mutants that cause hypertrophic cardiomyopathy. J. Biol. Chem. 275, 22069-22074 (2000).

28 Witt, C. C., Gerull, B., Davies, M. J., Centner, T., Linke, W. A. \& Thierfelder, L. Hypercontractile properties of cardiac muscle fibers in a knock-in mouse model of cardiac myosin-binding protein-C. J. Biol. Chem. 276, 5353-5359 (2001).

29 Roopnarine, O. Mechanical defects of muscle fibers with myosin light chain mutants that cause cardiomyopathy. Biophys. J. 84, 2440-2449 (2003).

30 Pinto, J. R., Parvatiyar, M. S., Jones, M. A., Liang, J., Ackerman, M. J. \& Potter, J. D. A functional and structural study of troponin $\mathrm{C}$ mutations related to hypertrophic cardiomyopathy. J. Biol. Chem. 284, 19090-19100 (2009).

31 Tyska, M. J., Hayes, E., Giewat, M., Seidman, C. E., Seidman, J. G. \& Warshaw, D. M. Single-molecule mechanics of $R 403 Q$ cardiac myosin isolated from the mouse model of familial hypertrophic cardiomyopathy. Circ. Res. 86, 737-744 (2000).
32 Satoh, M., Takahashi, M., Sakamoto, T., Hiroe, M., Marumo, F. \& Kimura, A. Structural analysis of the titin gene in hypertrophic cardiomyopathy: identification of a novel disease gene. Biochem. Biophys. Res. Commun. 262, 411-417 (1999).

33 Hayashi, T., Arimura, T., Itoh-Satoh, M., Ueda, K., Hohda, S., Inagaki, N. et al. Tcap gene mutations in hypertrophic cardiomyopathy and dilated cardiomyopathy. J. Am. Coll. Cardiol. 44, 2192-2201 (2004).

34 Cazorla, O., Wu, Y., Irving, T. C. \& Granzier, H. Titin-based modulation of calcium sensitivity of active tension in mouse skinned cardiac myocytes. Circ. Res. 88, 10281035 (2001).

35 Fujita, H., Labeit, D., Gerull, B., Labeit, S. \& Granzier, H. L. Titin isoform-dependent effect of calcium on passive myocardial tension. Am. J. Physiol. Heart Circ. Physiol. 287, H2528-H2534 (2004).

36 Fuchs, F. \& Martyn, D. A. Length-dependent $\mathrm{Ca}(2+)$ activation in cardiac muscle: some remaining questions. J. Muscle Res. Cell Motil. 26, 199-212 (2005).

37 Geier, C., Perrot, A., Ozcelik, C., Binner, P., Counsell, D., Hoffmann, K. et al. Mutations in the human muscle LIM protein gene in families with hypertrophic cardiomyopathy. Circulation 107, 1390-1395 (2003).

38 Gehmlich, K., Geier, C., Osterziel, K. J., Van der Ven, P. F. \& Fürst, D. O. Decreased interactions of mutant muscle LIM protein (MLP) with N-RAP and alpha-actinin and their implication for hypertrophic cardiomyopathy. Cell Tissue Res. 317, 129-136 (2004).

39 Mohapatra, B., Jimenez, S., Lin, J. H., Bowles, K. R., Coveler, K. J., Marx, J. G. et al. Mutations in the muscle LIM protein and alpha-actinin-2 genes in dilated cardiomyopathy and endocardial fibroelastosis. Mol. Genet. Metab. 80, 207-215 (2003).

40 Hayashi, T., Arimura, T., Ueda, K., Shibata, H., Hohda, S., Takahashi, M. et al. Identification and functional analysis of a caveolin-3 mutation associated with familial hypertrophic cardiomyopathy. Biochem. Biophys. Res. Commun. 313, 178-184 (2004).

41 Vasile, V. C., Ommen, S. R., Edwards, W. D. \& Ackerman, M. J. A missense mutation in a ubiquitously expressed protein, vinculin, confers susceptibility to hypertrophic cardiomyopathy. Biochem. Biophys. Res. Commun. 345, 998-1003 (2006).

42 Wang, X., Osinska, H., Klevitsky, R., Gerdes, A. M., Nieman, M., Lorenz, J. et al. Expression of R120G-alphaB-crystallin causes aberrant desmin and alphaB-crystallin aggregation and cardiomyopathy in mice. Circ. Res. 89, 84-91 (2001).

43 Landstrom, A. P., Weisleder, N., Batalden, K. B., Bos, J. M., Tester, D. J., Ommen, S. R. et al. Mutations in JPH2-encoded junctophilin-2 associated with hypertrophic cardiomyopathy in humans. J. Mol. Cell Cardiol. 42, 1026-1035 (2007).

44 Arimura, T., Matsumoto, Y., Okazaki, O., Hayashi, T., Takahashi, M., Inagaki, N. et al. Structural analysis of obscurin gene in hypertrophic cardiomyopathy. Biochem. Biophys. Res. Commun. 362, 281-287 (2007).

45 Arimura, T., Bos, M. J., Sato, A., Kubo, T., Okamoto, H., Nishi, H. et al. Cardiac ankyrin repeat protein gene (ANKRD1) mutations in hypertrophic cardiomyopathy. J. Am. Coll. Cardiol. 54, 334-342 (2009).

46 Rajasekaran, N. S., Connell, P., Christians, E. S., Yan, L. J., Taylor, R. P., Orosz, A. et al. Human alpha B-crystallin mutation causes oxido-reductive stress and protein aggregation cardiomyopathy in mice. Cell 130, 427-439 (2007).

47 Matsumoto, Y., Hayashi, T., Inagaki, N., Takahashi, M., Hiroi, S., Nakamura, T. et al. Functional analysis of titin/connectin N2-B mutations found in cardiomyopathy. J. Muscle Res. Cell Motil. 26, 367-374 (2005).

48 Inagaki, N., Hayashi, T., Arimura, T., Koga, Y., Takahashi, M., Shibata, H. et al. Alpha B-crystallin mutation in dilated cardiomyopathy. Biochem. Biophys. Res. Commun. 342, 379-386 (2006).

49 Kikuchi, T., Oka, N., Koga, A., Miyazaki, H., Ohmura, H. \& Imaizumi, T. Behavior of caveolae and caveolin-3 during the development of myocyte hypertrophy. J. Cardiovasc. Pharmacol. 45, 204-210 (2005).

50 Koga, A., Oka, N., Kikuchi, T., Miyazaki, H., Kato, S. \& Imaizumi, T. Adenovirusmediated overexpression of caveolin-3 inhibits rat cardiomyocyte hypertrophy. Hypertension 42, 213-219 (2003).

51 Young, P., Ehler, E. \& Gautel, M. Obscurin, a giant sarcomeric Rho guanine nucleotide exchange factor protein involved in sarcomere assembly. J. Cell Biol. 154, 123-136 (2001).

52 Aihara, Y., Kurabayashi, M., Saito, Y., Ohyama, Y., Tanaka, T., Takeda, S. et al. Cardiac ankyrin repeat protein is a novel marker of cardiac hypertrophy: role of M-CAT element within the promoter. Hypertension 36, 48-53 (2000).

53 Witt, S. H., Labeit, D., Granzier, H., Labeit, S. \& Witt, C. C. Dimerization of the cardiac ankyrin protein CARP: implications for MARP titin-based signaling. J. Muscle Res. Cell Motil. 262, 1-8 (2006)

54 Towbin, J. A., Hejtmancik, J. F., Brink, P., Gelb, B., Zhu, X. M., Chamberlain, J. S. et al. X-linked dilated cardiomyopathy. Molecular genetic evidence of linkage to the Duchenne muscular dystrophy (dystrophin) gene at the Xp21 locus. Circulation 87, 1854-1865 (1993)

55 Cohen, N. \& Muntoni, F. Multiple pathogenetic mechanisms in X linked dilated cardiomyopathy. Heart 90, 835-841 (2004).

56 Muntoni, F., Torelli, S. \& Ferlini, A. Dystrophin and mutations: one gene, several proteins, multiple phenotypes. Lancet Neurol. 2, 731-740 (2003).

57 Finsterer, J. \& Stöllberger, C. The heart in human dystrophinopathies. Cardiology 99, 1-19 (2003).

58 Lapidos, K. A., Kakkar, R. \& McNally, E. M. The dystrophin glycoprotein complex: signaling strength and integrity for the sarcolemma. Circ. Res. 94, 1023-1031 (2004).

59 Tsubata, S., Bowles, K. R., Vatta, M., Zintz, C., Titus, J., Muhonen, L. et al. Mutations in the human delta-sarcoglycan gene in familial and sporadic dilated cardiomyopathy. J. Clin. Invest. 106, 655-662 (2000). 
60 Knöll, R., Postel, R., Wang, J., Krätzner, R., Hennecke, G., Vacaru, A. M. et al. Laminin-alpha4 and integrin-linked kinase mutations cause human cardiomyopathy via simultaneous defects in cardiomyocytes and endothelial cells. Circulation 116 515-525 (2007)

61 Towbin, J. A. \& Bowles, N. E. Genetic abnormalities responsible for dilated cardiomyopathy. Curr. Cardiol. Rep. 2, 475-480 (2000).

62 Olson, T. M., Michels, V. V., Thibodeau, S. N., Tai, Y. S. \& Keating, M. T. Actin mutations in dilated cardiomyopathy, a heritable form of heart failure. Science $\mathbf{2 8 0}$, 750-752 (1998)

63 Mogensen, J., Klausen, I. C., Pedersen, A. K., Egeblad, H., Bross, P., Kruse, T. A. et al. Alpha-cardiac actin is a novel disease gene in familial hypertrophic cardiomyopathy. $J$. Clin. Invest. 103, R39-R43 (1999).

64 Vang, S., Corydon, T. J., Børglum, A. D., Scott, M. D., Frydman, J., Mogensen, J. et al. Actin mutations in hypertrophic and dilated cardiomyopathy cause inefficient protein folding and perturbed filament formation. FEBS J. 272, 2037-2049 (2005).

65 Kamisago, M., Sharma, S. D., DePalma, S. R., Solomon, S., Sharma, P., McDonough, B. et al. Mutations in sarcomere protein genes as a cause of dilated cardiomyopathy. N. Engl. J. Med. 343, 1688-1696 (2000).

66 Morimoto, S., Lu, Q. W., Harada, K., Takahashi-Yanaga, F., Minakami, R., Ohta, M. et al. $\mathrm{Ca}(2+)$-desensitizing effect of a deletion mutation Delta K210 in cardiac troponin T that causes familial dilated cardiomyopathy. Proc. Natl. Acad. Sci. USA 99, 913-918 (2002).

67 Chang, A. N. \& Potter, J. D. Sarcomeric protein mutations in dilated cardiomyopathy. Heart Fail. Rev. 10, 225-235 (2005).

68 Itoh-Satoh, M., Hayashi, T., Nishi, H., Koga, Y., Arimura, T., Koyanagi, T. et al. Titin mutations as the molecular basis for dilated cardiomyopathy. Biochem. Biophys. Res. Commun. 291, 385-393 (2002).

69 Knöll, R., Hoshijima, M., Hoffman, H. M., Person, V., Lorenzen-Schmidt, I., Bang, M. $\mathrm{L}$. et al. The cardiac mechanical stretch sensor machinery involves a $Z$ disc complex that is defective in a subset of human dilated cardiomyopathy. Cell 111, 943-955 (2002).

70 Zhou, Q., Ruiz-Lozano, P., Martone, M. E. \& Chen, J. Cypher, a striated musclerestricted PDZ and LIM domain-containing protein, binds to alpha-actinin-2 and protein kinase C. J. Biol. Chem. 274, 19807-19813 (1999).

71 Frey, N., Richardson, J. A. \& Olson, E. N. Calsarcins, a novel family of sarcomeric calcineurin-binding proteins. Proc. Natl. Acad. Sci. USA 97, 14632-14637 (2000).

72 Wilkins, B. J. \& Molkentin, J. D. Calcium-calcineurin signaling in the regulation of cardiac hypertrophy. Biochem. Biophys. Res. Commun. 322, 1178-1191 (2004).

73 Heineke, J. \& Molkentin, J. D. Regulation of cardiac hypertrophy by intracellular signalling pathways. Nature Rev. Mol. Cell Biol. 7, 589-600 (2006).

74 Heineke, J., Ruetten, H., Willenbockel, C., Gross, S. C., Naguib, M., Schaefer, A. et al. Attenuation of cardiac remodeling after myocardial infarction by muscle LIM proteincalcineurin signaling at the sarcomeric Z-disc. Proc. Natl. Acad. Sci. USA 102, 1655-1660 (2005)

75 Arimura, T., Hayashi, T., Terada, H., Lee, S. Y., Zhou, Q., Takahashi, M. et al. A Cypher/ ZASP mutation associated with dilated cardiomyopathy alters the binding affinity to protein kinase C. J. Biol. Chem. 279, 6746-6752 (2004).

76 Vatta, M., Mohapatra, B., Jimenez, S., Sanchez, X., Faulkner, G., Perles, Z. et al. Mutations in Cypher/ZASP in patients with dilated cardiomyopathy and left ventricular non-compaction. J. Am. Coll. Cardiol. 42, 2014-2027 (2003).

77 Arimura, T., Inagaki, N., Hayashi, T., Shichi, D., Sato, A., Hinohara, K. et al. Impaired binding of ZASP/Cypher with phosphoglucomutase 1 is associated with dilated cardiomyopathy. Cardiovasc. Res. 83, 80-88 (2009).

78 Li, D., Tapscoft, T., Gonzalez, O., Burch, P. E., Quiñones, M. A., Zoghbi, W. A. et al. Desmin mutation responsible for idiopathic dilated cardiomyopathy. Circulation 100, 461-464 (1999).

79 Olson, T. M., Illenberger, S., Kishimoto, N. Y., Huttelmaier, S., Keating, M. T. \& Jockusch, B. M. Metavinculin mutations alter actin interaction in dilated cardiomyopathy. Circulation 105, 431-437 (2002).

80 Taylor, M. R., Slavov, D., Ku, L., Di Lenarda, A., Sinagra, G., Carniel, E. et al. Prevalence of desmin mutations in dilated cardiomyopathy. Circulation 115, 1244-1251 (2007)

81 Duboscq-Bidot, L., Xu, P., Charron, P., Neyroud, N., Dilanian, G., Millaire, A. et al. Mutations in the Z-band protein myopalladin gene and idiopathic dilated cardiomyopathy. Cardiovasc. Res. 77, 118-125 (2008).

82 Fatkin, D., MacRae, C., Sasaki, T., Wolff, M. R., Porcu, M., Frenneaux, M. et al. Missense mutations in the rod domain of the lamin $A / C$ gene as causes of dilated cardiomyopathy and conduction-system disease. N. Engl. J. Med. 341, 1715-1724 (1999).

83 Bonne, G., Di Barletta, M. R., Varnous, S., Bécane, H. M., Hammouda, E. H., Merlini, L. et al. Mutations in the gene encoding lamin $\mathrm{A} / \mathrm{C}$ cause autosomal dominant EmeryDreifuss muscular dystrophy. Nature Genet. 21, 285-288 (1999).

84 Bione, S., Small, K., Aksmanovic, V. M., D'Urso, M., Ciccodicola, A., Merlini, L. et al. Identification of new mutations in the Emery-Dreifuss muscular dystrophy gene and evidence for genetic heterogeneity of the disease. Hum. Mol. Genet. 4, 1859-1863 (1995).

85 Morris, G. E. \& Manilal, S. Heart to heart: from nuclear proteins to Emery-Dreifuss muscular dystrophy. Hum. Mol. Genet. 8, 1847-1851 (1999).

86 Sylvius, N. \& Tesson, F. Lamin A/C and cardiac diseases. Curr. Opin. Cardiol. 21, 159-165 (2006).

87 Arimura, T., Helbling-Leclerc, A., Massart, C., Varnous, S., Niel, F., Lacène, E. et al. Mouse model carrying H222P-Lmna mutation develops muscular dystrophy and dilated cardiomyopathy similar to human striated muscle laminopathies. Hum. Mol. Genet. 14, 155-169 (2005).
88 Muchir, A., Pavlidis, P., Decostre, V., Herron, A. J., Arimura, T., Bonne, G. et al. Activation of MAPK pathways links LMNA mutations to cardiomyopathy in EmeryDreifuss muscular dystrophy. J. Clin. Invest. 117, 1282-1293 (2007).

89 Bienengraeber, M., Olson, T. M., Selivanov, V. A., Kathmann, E. C., O'Cochlain, F., Gao, F. et al. ABCC9 mutations identified in human dilated cardiomyopathy disrupt catalytic KATP channel gating. Nature Genet. 36, 382-387 (2004).

90 McNair, W. P., Ku, L., Taylor, M. R., Fain, P. R., Dao, D., Wolfel, E. et al. SCN5A mutation associated with dilated cardiomyopathy, conduction disorder, and arrhythmia. Circulation 110, 2163-2167 (2004).

91 Lehnart, S. E., Ackerman, M. J., Benson, D. W. Jr., Brugada, R., Clancy, C. E., Donahue, J. K. et al. Inherited arrhythmias: a National Heart, Lung, and Blood Institute and Office of Rare Diseases workshop consensus report about the diagnosis, phenotyping, molecular mechanisms, and therapeutic approaches for primary cardiomyopathies of gene mutations affecting ion channel function. Circulation 116, 2325-2345 (2007)

92 Arimura, T., Hayashi, T., Matsumoto, Y., Shibata, H., Hiroi, S., Nakamura, T. et al. Structural analysis of four and half LIM protein-2 in dilated cardiomyopathy. Biochem. Biophys. Res. Commun. 357, 162-167 (2007).

93 Johannessen, M., Møller, S., Hansen, T., Moens, U. \& Van Ghelue, M. The multifunctional roles of the four-and-a-half-LIM only protein FHL2. Cell Mol. Life Sci. 63, 268-284 (2006).

94 Moulik, M., Vatta, M., Witt, S. H., Alora, A. M., Murphy, R. T., McKenna, W. J. et al. ANKRD -the gene encoding cardiac ankyrin repeat protein- is a novel dilated cardiomyopathy gene. J. Am. Coll. Cardiol. 54, 325-333 (2009).

95 Hoshijima, M., Knöll, R., Pashmforoush, M. \& Chien, K. R. Reversal of calcium cycling defects in advanced heart failure toward molecular therapy. J. Am. Coll. Cardiol. 48, A15-A23 (2006).

96 Schmitt, J. P., Kamisago, M., Asahi, M., Li, G. H., Ahmad, F., Mende, U. et al. Dilated cardiomyopathy and heart failure caused by a mutation in phospholamban. Science 299, 1410-1413 (2003).

97 Haghighi, K., Kolokathis, F., Gramolini, A. O., Waggoner, J. R., Pater, L., Lynch, R. A. et al. A mutation in the human phospholamban gene, deleting arginine 14 , results in lethal, hereditary cardiomyopathy. Proc. Natl. Acad. Sci. USA 103, 1388-1393 (2006).

98 Chiu, C., Tebo, M., Ingles, J., Yeates, L., Arthur, J. W., Lind, J. M. et al. Genetic screening of calcium regulation genes in familial hypertrophic cardiomyopathy. J. Mol. Cell Cardiol. 43, 337-343 (2007).

99 Koss, K. L., Grupp, I. L. \& Kranias, E. G. The relative phospholamban and SERCA2 ratio: a critical determinant of myocardial contractility. Basic Res. Cardiol. 92, S17-S24 (1997).

100 Minamisawa, S., Hoshijima, M., Chu, G., Ward, C. A., Frank, K., Gu, Y. et al. Chronic phospholamban-sarcoplasmic reticulum calcium ATPase interaction is the critical calcium cycling defect in dilated cardiomyopathy. Cell 99, 313-322 (1999).

101 Hoshijima, M., Ikeda, Y., Iwanaga, Y., Minamisawa, S., Date, M. O., Gu, Y. et al. Chronic suppression of heart-failure progression by a pseudophosphorylated mutant of phospholamban via in vivo cardiac rAAV gene delivery. Nature Med. 8, 864-871 (2002).

102 Nigro, V., Okazaki, Y., Belsito, A., Piluso, G., Matsuda, Y., Politano, L. et al. Identification of the Syrian hamster cardiomyopathy gene. Hum. Mol. Genet. 6, 601-607 (1997).

103 Minamisawa, S., Sato, Y., Tatsuguchi, Y., Fujino, T., Imamura, S., Uetsuka, Y. et al. Mutation of the phospholamban promoter associated with hypertrophic cardiomyopathy. Biochem. Biophys. Res. Commun. 304, 1-4 (2003).

104 Medin, M., Hermida-Prieto, M., Monserrat, L., Laredo, R., Rodriguez-Rey, J. C., Fernandez, X. et al. Mutational screening of phospholamban gene in hypertrophic and idiopathic dilated cardiomyopathy and functional study of the PLN-42 C>G mutation. Eur. J. Heart Fail. 9, 37-43 (2007).

105 Kadambi, V. J., Ponniah, S., Harrer, J. M., Hoit, B. D., Dorn, G. W. II, Walsh, R. A. et al. Cardiac-specific overexpression of phospholamban alters calcium kinetics and resultant cardiomyocyte mechanics in transgenic mice. J. Clin. Invest. 97, 533-539 (1996)

106 Barth, P. G., Valianpour, F., Bowen, V. M., Lam, J., Duran, M., Vaz, F. M. et al. X-linked cardioskeletal myopathy and neutropenia (Barth syndrome): an update. Am. J. Med. Genet. A 126, 349-354 (2004).

107 Murakami, T., Hayashi, Y. K., Noguchi, S., Ogawa, M., Nonaka, I., Tanabe, Y. et al. Fukutin gene mutations cause dilated cardiomyopathy with minimal muscle weakness. Ann. Neurol. 60, 597-602 (2006).

108 Norgett, E. E., Hatsell, S. J., Carvajal-Huerta, L., Cabezas, J. C., Common, J., Purkis, P. E. et al. Recessive mutation in desmoplakin disrupts desmoplakin-intermediate filament interactions and causes dilated cardiomyopathy, woolly hair and keratoderma. Hum. Mol. Genet. 9, 2761-2766 (2000)

109 Uzumcu, A., Norgett, E. E., Dindar, A., Uyguner, O., Nisli, K., Kayserili, H. et al. Loss of desmoplakin isoform I causes early onset cardiomyopathy and heart failure in a Naxos-like syndrome. J. Med. Genet. 43, e5 (2006).

110 Arimura, T., Hayashi, Y. K., Murakami, T., Oya, Y., Funabe, S., Hirasawa, E. A. et al. Mutational analysis of fukutin gene in dilated cardiomyopathy and hypertrophic cardiomyopathy. Circ. J. 73, 158-161 (2009).

111 Pinto, J. R., Parvatiyar, M. S., Jones, M. A., Liang, J. \& Potter, J. D. A troponin T mutation that causes infantile restrictive cardiomyopathy increases $\mathrm{Ca} 2+$ sensitivity of force development and impairs the inhibitory properties of troponin. J. Biol. Chem. 283, 2156-2166 (2008)

112 Yumoto, F., Lu, Q. W., Morimoto, S., Tanaka, H., Kono, N., Nagata, K. et al. Drastic $\mathrm{Ca} 2+$ sensitization of myofilament associated with a small structural change in 
troponin I in inherited restrictive cardiomyopathy. Biochem. Biophys. Res. Commun. 338, 1519-1526 (2005).

113 Kubo, T., Gimeno, J. R., Bahl, A., Steffensen, U., Steffensen, M., Osman, E. et al. Prevalence, clinical significance, and genetic basis of hypertrophic cardiomyopathy with restrictive phenotype. J. Am. Coll. Cardiol. 49, 2419-2426 (2007).

114 Mogensen, J., Kubo, T., Duque, M., Uribe, W., Shaw, A., Murphy, R. et al. Idiopathic restrictive cardiomyopathy is part of the clinical expression of cardiac troponin I mutations. J. Clin. Invest. 111, 209-216 (2003).

115 Murphy, R. T., Mogensen, J., Shaw, A., Kubo, T., Hughes, S. \& McKenna, W. J. Novel mutation in cardiac troponin I in recessive idiopathic dilated cardiomyopathy. Lancet 363, 371-372 (2004).

116 Budde, B. S., Binner, P., Waldmüller, S., Höhne, W., Blankenfeldt, W., Hassfeld, S. et al. Noncompaction of the ventricular myocardium is associated with a de novo mutation in the beta-myosin heavy chain gene. PLOS ONE 2, e1362 (2007).

117 Monserrat, L., Hermida-Prieto, M., Fernandez, X., Rodríguez, I., Dumont, C., Cazón, L. et al. Mutation in the alpha-cardiac actin gene associated with apical hypertrophic cardiomyopathy, left ventricular non-compaction, and septal defects. Eur. Heart J. 28, 1953-1961 (2007).

118 Hermida-Prieto, M., Monserrat, L., Castro-Beiras, A., Laredo, R., Soler, R., Peteiro, J. et al. Familial dilated cardiomyopathy and isolated left ventricular noncompaction associated with lamin A/C gene mutations. Am. J. Cardiol. 94, 50-54 (2004).

119 Bleyl, S. B., Mumford, B. R., Thompson, V., Carey, J. C., Pysher, T. J., Chin, T. K. et al. Neonatal, lethal noncompaction of the left ventricular myocardium is allelic with Barth syndrome. Am. J. Hum. Genet. 61, 868-872 (1997).

120 Ichida, F., Tsubata, S., Bowles, K. R., Haneda, N., Uese, K., Miyawaki, T. et al. Novel gene mutations in patients with left ventricular noncompaction or Barth syndrome. Circulation 103, 1256-1263 (2001).

121 Chen, H., Shi, S., Acosta, L., Li, W., Lu, J., Bao, S. et al. BMP10 is essential for maintaining cardiac growth during murine cardiogenesis. Development 131, 22192231 (2004).

122 Neuhaus, H., Rosen, V. \& Thies, R. S. Heart specific expression of mouse BMP-10 a novel member of the TGF-beta superfamily. Mech. Dev. 80, 181-184 (1999).
123 Nakano, N., Hori, H., Abe, M., Shibata, H., Arimura, T., Sasaoka, T. et al. Interaction of BMP10 with Tcap may modulate the course of hypertensive cardiac hypertrophy. Am. J. Physiol. Heart Circ. Physiol. 293, H3396-H3403 (2007).

124 van Tintelen, J. P., Hofstra, R. M., Wiesfeld, A. C., van den Berg, M. P., Hauer, R. N. \& Jongbloed, J. D. Molecular genetics of arrhythmogenic right ventricular cardiomyopathy: emerging horizon? Curr. Opin. Cardiol. 22, 185-192 (2007).

125 McKoy, G., Protonotarios, N., Crosby, A., Tsatsopoulou, A., Anastasakis, A., Coonar, A. et al. Identification of a deletion in plakoglobin in arrhythmogenic right ventricular cardiomyopathy with palmoplantar keratoderma and woolly hair (Naxos disease). Lancet 355, 2119-2124 (2000).

126 Alcalai, R., Metzger, S., Rosenheck, S., Meiner, V. \& Chajek-Shaul, T. A recessive mutation in desmoplakin causes arrhythmogenic right ventricular dysplasia, skin disorder, and woolly hair. J. Am. Coll. Cardiol. 42, 319-327 (2003).

127 Gerull, B., Heuser, A., Wichter, T., Paul, M., Basson, C. T., McDermott, D. A. et al. Mutations in the desmosomal protein plakophilin-2 are common in arrhythmogenic right ventricular cardiomyopathy. Nature Genet. 36, 1162-1164 (2004).

128 Pilichou, K., Nava, A., Basso, C., Beffagna, G., Bauce, B., Lorenzon, A. et al. Mutations in desmoglein-2 gene are associated with arrhythmogenic right ventricular cardiomyopathy. Circulation 113, 1171-1179 (2006).

129 Tiso, N., Stephan, D. A., Nava, A., Bagattin, A., Devaney, J. M., Stanchi, F. et al. Identification of mutations in the cardiac ryanodine receptor gene in families affected with arrhythmogenic right ventricular cardiomyopathy type 2 (ARVD2). Hum. Mol. Genet. 10, 189-194 (2001).

130 Beffagna, G., Occhi, G., Nava, A., Vitiello, L., Ditadi, A., Basso, C. et al. Regulatory mutations in transforming growth factor-beta3 gene cause arrhythmogenic right ventricular cardiomyopathy type 1. Cardiovasc. Res. 65, 366-373 (2005).

131 Tadano, N., Morimoto, S., Yoshimura, A., Miura, M., Yoshioka, K., Sakato, M. et al. $\mathrm{SCHOOO13,} \mathrm{a} \mathrm{novel} \mathrm{Ca}(2+)$ sensitizer with positive inotropic and no chronotropic action in heart failure. J. Pharmacol. Sci. 97, 53-60 (2005).

132 Arimura, T., Sato, R., Machida, N., Bando, H., Zhang, D. Y., Morimoto, S. et al. Improvement of left ventricular dysfunction and survival prognosis of dilated cardiomyopathy by administration of calcium sensitizer $\mathrm{SCHOOO13}$ in a mouse model. J. Am. Coll. Cardiol. (in press). 